\title{
Preliminary safety studies for the DEMO HCPB blanket concept
}

\author{
X. Jina), D. Carlonia), L.V. Boccaccinia), R. Stieglitza), T. Pinnab), D. Dongiovannib)
}

\section{List of Postulated Initiating Event (PIEs) from FFMEA}

\begin{tabular}{|c|c|}
\hline PIE & Description \\
\hline FB1 & $\begin{array}{l}\text { Loss of flow in all FW-BK (first wall blanket) cooling channels of one } \\
\text { section from total four coolant distribution sections for the outboard or } \\
\text { inboard segments ( } 48 \text { or } 32 \text { ) because stop of circulators for CCF (common } \\
\text { cause failure) }\end{array}$ \\
\hline FB2 & $\begin{array}{l}\text { Reduction of flow in all FW-BK cooling channels of one section of the } \\
\text { outboard or inboard segments because stop of circulator in one SG (steam } \\
\text { generator) line }\end{array}$ \\
\hline FB3 & $\begin{array}{l}\text { Reduction of flow in cooling channels of one FW-BK module because } \\
\text { internal clogging }\end{array}$ \\
\hline AOP1 & Loss of off-site power $<1 \mathrm{~h}$ \\
\hline AOP2 & Loss of off-site power from $1 \mathrm{~h}$ up to $32 \mathrm{~h}$ \\
\hline HB1 & $\begin{array}{l}\text { Loss of heat sink in all FW-BK primary cooling circuits because trip of both } \\
\text { HP (high pressure) and LP (low pressure) turbines due to loss of } \\
\text { condenser vacuum }\end{array}$ \\
\hline HB2 & Loss of heat sink in one FW-BK cooling train \\
\hline LBB1 & $\begin{array}{l}\text { Loss of FW-BK cooling circuit inside breeder blanket box: rupture of a } \\
\text { sealing weld }\end{array}$ \\
\hline LBB2 & $\begin{array}{l}\text { Loss of FW-BK cooling circuit inside breeder blanket box: leak of a sealing } \\
\text { weld }\end{array}$ \\
\hline LBO1 & $\begin{array}{l}\text { LOCA Out-VV because large rupture of He manifold feeder inside PHTS } \\
\text { vault }\end{array}$ \\
\hline LBO2 & $\begin{array}{l}\text { LOCA Out-VV because small rupture of He manifold feeder inside PHTS } \\
\text { vault }\end{array}$ \\
\hline LBO3 & LOCA Out-VV because rupture of tubes in a steam generator (SG) \\
\hline LBV1 & $\begin{array}{l}\text { Loss of FW-BK cooling circuit integrity inside VV: Rupture of FW-BK } \\
\text { module }\end{array}$ \\
\hline LBV2 & $\begin{array}{l}\text { Loss of FW-BK cooling circuit integrity inside VV: Leak from FW-BK } \\
\text { module }\end{array}$ \\
\hline TBO2 & $\begin{array}{l}\text { Small rupture from PHTS CPS process line inside the PHTS vault (Outside } \\
\text { VV), i.e. significant amount of tritium released into building }\end{array}$ \\
\hline $\mathrm{N} / \mathrm{S}$ & Not Safety Relevant \\
\hline
\end{tabular}

\section{Priority list of the event sequences}

* Loss of power: AOP2

* LOFA inducing in-vessel LOCA: FB1

* Ex-vessel LOCA inducing in-vessel LOCA: LBO1, LBO3

* Loss of heat sink due to loss of condenser in the SWCS: HB1

* In-box LOCA inducing in-vessel LOCA: LBB1

Proposal of the most severe accidents affecting the plant safety

\section{* Station Blackout (SBO)}

A total loss of all alternating current $(A C)$ power as a result of complete failure of both off-site and on-site AC power sources $\Rightarrow$ stop of all circulators, pumps and emergency diesel generators.

\section{* Bounding accident}

No active cooling, no active safety system operating, and no intervention for a prolonged period are foreseen - the worst consequences of an accident driven by in-plant energies.

\section{Safety risk approach}

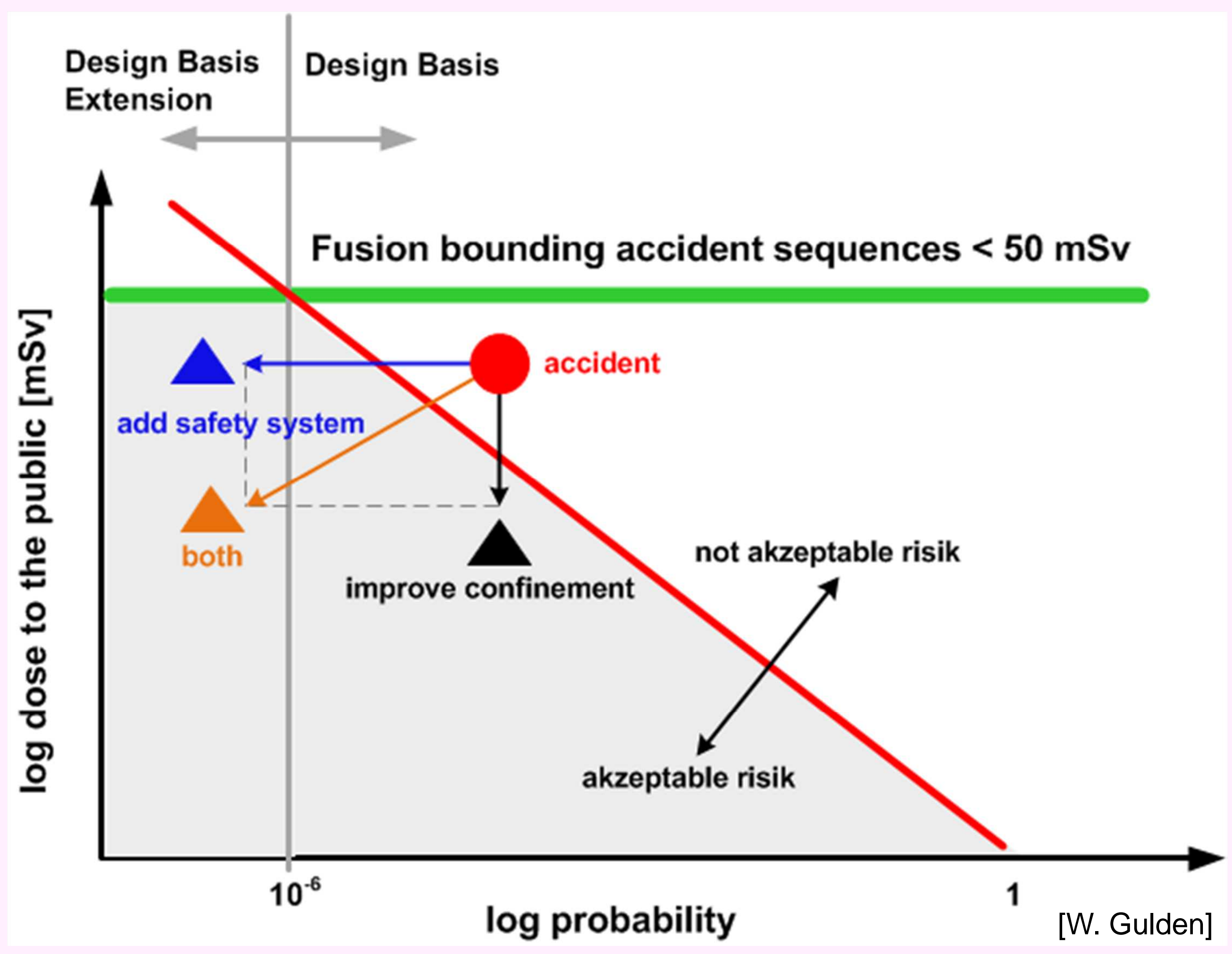

\section{Confinement scheme*}

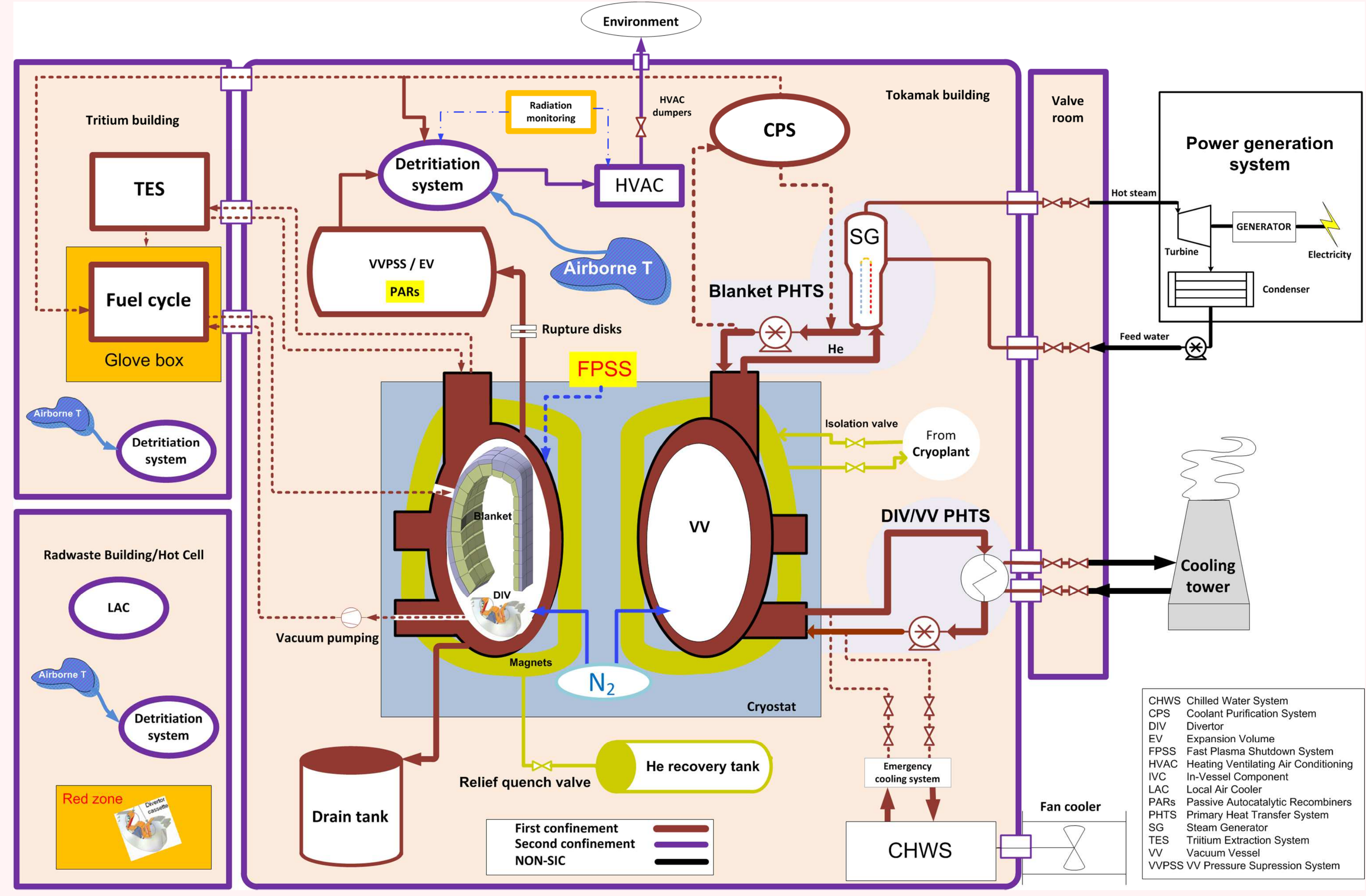

"The scheme will be updated in the on-going safety program of EUROfusion.

Main safety systems

- VV and its extension (1 ${ }^{\text {st }}$ barrier, $1^{\text {st }}$ confinement)

- VVPSS/EV (2 ${ }^{\text {nd }}$ barrier, $1^{\text {st }}$ confinement)

- Cryostat (decay heat remove)

- FPSS (plasma termination)

- Emergency cooling (2nd barrier, $1^{\text {st }}$ confinement)

- Tokamak and Tritium Building (3 $3^{\text {rd }}$ barrier, $2^{\text {nd }}$ confinement)

- HVAC, N-VDS and S-VDS ( $3^{\text {rd }}$ barrier, $2^{\text {nd }}$ confinement)

- Common release point ( $3^{\text {rd }}$ barrier, $2^{\text {nd }}$ confinement)

- Nitrogen injection / PAR (Passive Autocatalytic Recombiner, avoid $\mathrm{H}_{2}$ explosion)

- Coil fast discharge system (avoid arc in magnets, avoid short in magnets)

- Emergency power supply (supply emergency safety systems)

- Fire barriers / suppression (prevent propagation of fire)

\section{Safety relevant sources}

\section{* Energy}

- In operation: enthalpy in structure and coolant, plasma thermal energy, magnetic energy

- Decay heat after the plasma shutdown

- Energy from exothermal chemical reactions between materials (e.g. Be-air/steam etc.)

- Energy release due to postulated $\mathrm{H}_{2}$ explosion $\left(\mathrm{H}_{2}\right.$ production due to possible $\mathrm{Be}$ steam or W-steam reaction by water cooling)

* Tritium

- In the VV (PFC, blanket structure, $\mathrm{Li}_{4} \mathrm{SiO}_{4}, \mathrm{Be}, \mathrm{He}$ coolant, He purge gas, armor W of divertor, divertor structural and heat sink materials, water coolant, Tokamak dust, etc.)

- Out of the VV (PHTSs, TES, tritium plant, hot cells, cryogenic system, etc.)

- Tritium losses into the environment

- Tritium decay

- Activation products

- in structures, Tokamak dust and coolant (corrosion)

- Activated structural materials constituting the in-vessel components are made of $W$ alloys, copper alloys and EUROFER

* Dust

- aerosol particulate, broken flakes, globules, chunks, and other debris in the VV

- radio-toxicity due to the high activation of tungsten

- remove from the $\mathrm{VV}$, if its inventory will approach the safety limit

* ACPs

- in the divertor, VV cooling loops and other cooling loops related to auxiliary heating or diagnostics equipment using water as coolant

* Neutron sputtering products

- neutron-induced sputtering as mechanism to produce radioactive inventories in the heat transfer system
KIT - University of the State of Baden-Wuerttemberg and National Research Center of the Helmholtz Association $2^{\text {th }}$ Symposium on Fusion Technology 29th Sept. - 3rd October 2014, San Sebastian Spain 